\title{
The effect of soil properties and climate on phytocoenoses biodiversity in the forest-steppe zone of West Siberia
}

\author{
Alexander I. Syso ${ }^{1 *}$, Andrey Y. Korolyuk ${ }^{2}$, Boris A. Smolentsev ${ }^{1}$ \\ ${ }^{1}$ Institute of Soil Science and Agrochemistry of the SB RAS, 630090 Novosibirsk, Russia \\ ${ }^{2}$ Central Siberian Botanical Garden of the SB RAS, 630090 Novosibirsk, Russia
}

\begin{abstract}
The effect of weather conditions and such soil properties as $\mathrm{pH}$, salt content, as well as different forms of macro- and trace elements, on phytocoenoses biodiversity and chemical element contents in the aboveground phytomass was investigated in the forest-steppe zone of the West Siberian plain. Soil chemical element composition and salinity content were found to affect the phytomass content of $\mathrm{N}, \mathrm{P}, \mathrm{K}, \mathrm{Na}, \mathrm{Ca}, \mathrm{Mg}$, $\mathrm{Fe}, \mathrm{Mn}, \mathrm{Zn}, \mathrm{Cu}, \mathrm{Sr}$, Li.
\end{abstract}

\section{Introduction}

In the south of the West Siberian plain saline and water-logged mire landscapes are widely spread. Cyclical alternations of the 'cool and wet' climatic periods with the "warm and dry" ones are also common. Climate change cycles of various longevity [1] in these area have always exerted strong influence on soil and vegetation evolution and shifts of the boundary between the forest and the steppe. Climate aridization was found to increase soil salinity, decrease grassland productivity and mire-forming processes, whereas climate humidization brought about decreased soil salinity, increased grassland productivity, accelerated mire formation and mire area extension [2].

The forest-steppe zone of West Siberia represents the most densely populated area with plenty of land in agricultural use. However, landscapes with saline soils and climate cyclicality determine the high risk of land use. Vegetation in the forest-steppe of West Siberia readily responds to the global climate change. Therefore the studies of the influence of climate changes and soil properties on the forest-steppe phytocoenoses biodiversity are very actual for assessing the ecological status of the forest-steppe terrestrial ecosystems and their potential use. Relationship between soil properties, plant community biodiversity and chemical element contents in phytomass of meadow plants remain poorly investigated.

\section{Material and methods}

The study was conducted in 2017-2018 on the catena on the northern slope of the Pankratov Island of the dried Yudin stretch of the Chany Lake in the forest-steppe zone of

\footnotetext{
* Corresponding author: syso@issa-siberia.ru
} 
the West Siberian plain. Elementary geochemical landscapes were distinguished at the four geochemically linked catena positions. In July of both study years the plant species composition and soils were described, and samples the dominant species aboveground phytomass and soils $(0-20 \mathrm{~cm})$ were collected for chemical analyses. Soils were identified according to the Russian [3] and international classifications [4].

Soil samples were analyzed for particles $(<0.01 \mathrm{~mm})$ content by sedimentation method; for organic carbon (SOC) content by dichromate digestion in sulfuric acid; labile phosphorus $\left(\mathrm{P}_{2} \mathrm{O}_{5}\right)$ content, extracted by $0.5 \mathrm{M}$ acetic acid solution, was measured calorimetrically. Specific electric conductivity (SEC) was measured by conductometry in water extracts (1:5 soil: water), the total non-dissolved solids content was measured gravimetrically, and soil $\mathrm{pH}$ was determined potentiometrically. Capillary electrophoresis was used to determine concentrations of sulfate and chloride anions and potassium, sodium, calcium and magnesium cations. Chemical element contents were evaluated by atomic emission and atomic absorption techniques. The data are presented on the air-dried basis. Statistical analysis was performed using Excel software.

\section{Results and discussion}

The chemical element composition of soils of the studied catena was found to have rather homogenous content of macro- and trace chemical elements, both in total and mobile forms (Table 1,2).

Downwards the studied catena, i.e. from its eluvial to the accumulative geochemical positions, soil taxonomy, composition and properties were found to change, and phytocoenoses biodiversity and other characteristics changed as well (Table 1). The years of the study were the years of the cyclical change in climate. The years differed significantly in their weather conditions, primarily in the spring-summer period from May till August, in total atmospheric precipitation and average temperature: 2017 was warm and dry, whereas 2018 was cool and wet.

As compared with 2017, in 2018 the markedly increased spring-summer precipitation resulted in the increased number of plant species, especially on saline soils. Projective cover was estimated as ranging from 75 to $40 \%$ in the dry year and from 95 to $50 \%$ in the wet year. In general downwards the catena we found a decrease in the total and relative abundance of the plant species, susceptible to soil and climate environmental conditions and having a certain economic importance as animal feed or medicinal raw material. Alongside with the decrease, an increase in the abundance of xerophytes or halophytes was observed along the entire catena or its part.

We believe that changes in plant species composition and other phytocoenoses properties were determined by the changes in soil composition and properties. Among the latter the most important one was the decrease in the labile phosphorus content downwards the studied catena from the very high level of $200 \mathrm{mg} \mathrm{P}_{2} \mathrm{O}_{5} / \mathrm{kg}$ soil in chernozem to the low level of $38 \mathrm{mg} \mathrm{P}_{2} \mathrm{O}_{5} / \mathrm{kg}$ soil in solonets and almost non in solonchak, respectively (Table 1).

Table 1. Phytocoenoses and soil properties in the catena ecosystems in years with different weather conditios.

\begin{tabular}{|c|c|c|c|c|}
\hline $\begin{array}{c}\text { Geochemical } \\
\text { position of the } \\
\text { catena }\end{array}$ & Eluvial & Transit-eluvial & $\begin{array}{c}\text { Transit- } \\
\text { accumulative }\end{array}$ & Accumulative \\
\hline Phytocoenoses & $\begin{array}{c}\text { Meadow } \\
\text { dominated by } \\
\text { herbs and } \\
\text { grasses }\end{array}$ & $\begin{array}{c}\text { Meadow } \\
\text { dominated by } \\
\text { grasses and } \\
\text { saltwarts }\end{array}$ & Reed meadow & $\begin{array}{c}\text { Reed and sea } \\
\text { pink meadow }\end{array}$ \\
\hline
\end{tabular}




\begin{tabular}{|c|c|c|c|c|c|c|c|c|}
\hline \multirow{2}{*}{$\begin{array}{c}\text { Soils named } \\
\text { according to WRB } \\
2014[4] \\
\text { Year }\end{array}$} & \multicolumn{2}{|c|}{$\begin{array}{c}\text { Haplic } \\
\text { Chernozems } \\
\text { (Protosodic) }\end{array}$} & \multicolumn{2}{|c|}{$\begin{array}{l}\text { Stagnic Solonetz } \\
\text { (Siltic, Humic) }\end{array}$} & \multicolumn{2}{|c|}{$\begin{array}{c}\text { Stagnic } \\
\text { Hypocalcic } \\
\text { Gleysols } \\
\text { (Loamic, Salic) }\end{array}$} & \multicolumn{2}{|c|}{$\begin{array}{l}\text { Gleyic Fluvic } \\
\text { Solonchaks } \\
\text { (Arenic, } \\
\text { Chloridic) }\end{array}$} \\
\hline & 2017 & 2018 & 2017 & 2018 & 2017 & 2018 & 2017 & 2018 \\
\hline \multicolumn{9}{|c|}{ May-August weather conditions } \\
\hline $\begin{array}{l}\text { Total precipitation, } \\
\mathrm{mm}\end{array}$ & 113 & 242 & 113 & 242 & 113 & 242 & 113 & 242 \\
\hline $\begin{array}{c}\text { Average } \\
\text { temperature, }{ }^{\circ} \mathrm{C}\end{array}$ & 17.7 & 15.4 & 17.7 & 15.4 & 17.7 & 15.4 & 17.7 & 15.4 \\
\hline \multicolumn{9}{|c|}{ Phytocoenoses } \\
\hline Species richness & 35 & 41 & 31 & 39 & 17 & 40 & 16 & 23 \\
\hline Projective cover, $\%$ & 75 & 95 & 65 & 70 & 60 & 60 & 40 & 50 \\
\hline \multicolumn{9}{|c|}{ Soil properties and composition } \\
\hline $\begin{array}{c}\text { Particles }<0.01 \mathrm{~mm} \text {, } \\
\%\end{array}$ & 37.7 & 37.9 & 23.0 & 22.0 & 36.9 & 39.6 & 8.6 & 10.7 \\
\hline SOC, $\%$ & 2.0 & - & 2.2 & - & 2.2 & - & 0.3 & - \\
\hline Labile $\mathrm{P}_{2} \mathrm{O}_{5}, \mathrm{mg} / \mathrm{kg}$ & 213 & - & 38 & - & 0.2 & - & 0.2 & - \\
\hline $\mathrm{pH}$ (in water) & 6.4 & 6.6 & 6.4 & 6.3 & 7.8 & 8.4 & 8.1 & 9.0 \\
\hline Solid residue, $\%$ & 0.13 & 0.04 & 0.11 & 0.06 & 0.15 & 0.08 & 0.24 & 0.26 \\
\hline $\mathrm{SEC}, \mu \mathrm{S} / \mathrm{cm}$ & 89 & 46 & 64 & 58 & 184 & 179 & 711 & 1167 \\
\hline $\mathrm{SO}_{4}, \mathrm{mg} / \mathrm{kg}$ & 20 & 8 & 50 & 13 & 250 & 25 & 50 & 895 \\
\hline $\mathrm{Cl}, \mathrm{mg} / \mathrm{kg}$ & 30 & 6 & 30 & 8 & 30 & 6 & 30 & 1107 \\
\hline $\mathrm{K}, \mathrm{mg} / \mathrm{kg}$ & 108 & 110 & 36 & 24 & 82 & 37 & 57 & 55 \\
\hline $\mathrm{Na}, \mathrm{mg} / \mathrm{kg}$ & 21 & 22 & 28 & 29 & 86 & 85 & 390 & 117 \\
\hline $\mathrm{Ca}, \mathrm{mg} / \mathrm{kg}$ & 27 & 6 & 24 & 12 & 69 & 53 & 69 & 180 \\
\hline $\mathrm{Mg}, \mathrm{mg} / \mathrm{kg}$ & 32 & 7 & 20 & 10 & 60 & 27 & 69 & 93 \\
\hline $\mathrm{K} / \mathrm{Na}$ & 5.1 & 5.0 & 1.3 & 0.8 & 1.0 & 0.4 & 0.1 & 0.5 \\
\hline
\end{tabular}

Such decrease was of greatest importance for important resource plants, susceptible to mineral nutrition and water availability. Negative influence on plants was also exerted by alkalinity and salinity, increasing downwards the catena. Increased sodium (potassium antagonist) concentration and decreased $\mathrm{K} / \mathrm{Na}$ ratio down the catena indicated lower availability of soil potassium for plant uptake.

Analysis of plant community composition and soil changes from the eluvial down to the accumulative catena positions revealed strong negative correations between the plant biodiversity and soil $\mathrm{pH}$ and salt content $(\mathrm{P} \leq 0.05)$.

For most of the economically important herbaceous and gramineous plant species the soil environment can be considered to be not beneficial for their growth, starting already at weakly alkaline reaction $\left(\mathrm{pH}_{\text {water }}\right.$ ranging 7.6-8.0), water-soluble salts content exceeding $0.15 \%$ and labile phosphorus decreased to a moderate level. Critical conditions for survival even of salt-tolerant plants in saline landscapes were found to occur at the medium-alkaline soil reaction $\left(\mathrm{pH}_{\text {water }}\right.$ exceeding 8.1), salt concentration exceeding $0.2 \%$ under sulphatesodium ions prevalence, and low labile phosphorus content.

Soil $\mathrm{pH}$ and salinity displayed different correlation patterns with total nitrogen and phosphorus content, as well as with the contents of water-soluble forms of macro- and trace elements in the aboveground biomass of dominant plant species Calamagrostis epigeios (L.) Roth и Galatella biflora (L.) Nees (Table 2). 
Increased alkalinity and salinity were found to result in the increased $\mathrm{Ca}, \mathrm{Mg}, \mathrm{Sr}, \mathrm{Li}$ concentrations and decreased $\mathrm{P}$ and $\mathrm{Mn}$ concentrations in plants. It should be noted that increased concentration of water-soluble $\mathrm{Ca}$ and $\mathrm{Mg}$ in soils and plants negatively affected $\mathrm{P}, \mathrm{K}, \mathrm{Fe}, \mathrm{Mn}, \mathrm{Cu}$ and $\mathrm{Zn}$ accumulation in plants.

Table 2. Correlation between soil solution reaction $(\mathrm{pH})$, solid residue content in water extracts and chemical element contents in the aboveground phytomass of the dominant plant species in different catena ecosystems.

\begin{tabular}{|c|c|c|c|c|c|c|c|c|c|c|c|}
\hline \multirow{2}{*}{ Property } & $\mathrm{N}$ & $\mathrm{P}$ & $\mathrm{Ca}$ & $\mathrm{Mg}$ & $\mathrm{K}$ & $\mathrm{Na}$ & $\mathrm{Sr}$ & $\mathrm{Li}$ & $\mathrm{Mn}$ & $\mathrm{Zn}$ & $\mathrm{Cu}$ \\
\cline { 2 - 12 } & $\begin{array}{c}\text { Total } \\
\text { content }\end{array}$ & \multicolumn{10}{c|}{ Calamagrostis epigeios } \\
\hline \multicolumn{10}{|c|}{ Galatella biflora form content } \\
\hline $\mathrm{pH}$ & -0.5 & -1.0 & 0.6 & 0.9 & -0.8 & -1.0 & 0.5 & 1.0 & -0.9 & 0.9 & 0.9 \\
\hline Solid residue & 0.0 & -0.8 & 0.9 & 0.7 & -0.4 & -0.7 & 0.9 & 0.9 & -0.8 & -0.1 & 0.9 \\
\hline \multicolumn{10}{|c|}{} \\
\hline
\end{tabular}

The meadows of the forest-steppe in West Siberia are an important source of phytomass for cattle as fodder and for pharmaceutical industry as medicinal plants. Ecological and biogeochemical assessment of chemical element contents in plants showed that in the studied meadow ecosystems forage herbs and grasses generally had cobalt, copper, molybdenum concentrations that were lower than the critical (threshold) concentrations [5], which can lead to the dietary deficit of these elements in animals and, as a consequence, to the increased possibility of disorders and diseases. Another reason for animal diseases can be $\mathrm{Ca} / \mathrm{Sr}$ and $\mathrm{Ca} / \mathrm{P}$ ratios in the fodder when they are lower than the values beneficial for animal health.

Our studies showed that vegetation biodiversity and phytomass chemical element contents in the natural meadows of the forest-steppe zone in West Siberia are rather dynamic, depending on several environmental factors: 1) climate humidity/aridity cycles, as climate aridization leads to soil moisture deficit and increased salinity of soil solution, and, consequently, to increased contribution of xerophytes and halophytes in phytocoenoses; 2) the level and chemical character of soil salinity and $\mathrm{pH}$, critical levels of which are not similar for different plant species; and 3) the content of soil mineral nutrients available for plant uptake, for instance, phosphorus; decreased contents of such nutrients result in poor productivity and mineral composition of plants and decreased relative abundance of eutrophic and mesotrophic plant species.

\section{References}

1. I. M. Ablova, Omsk Scientific Bulletin, 1(84) (2009)

2. A. I. Syso, A. M. Peregon, Contemporary Problems of Ecology, 2, 2, (2009)

3. Classification and Diagnostics of the Soils of Russia (Smolensk, Oikumena, 2004)

4. IUSS Working Group, WRB, World Reference Base for Soil Resources 2014 (Roma, FAO, 2014)

5. V. V. Ermakov, S. F. Tyutikov, Geochemical ecology of animals (Moscow, Nauka, 2008) 